\title{
ANALISIS PENGARUH LIKUIDITAS, PROFITABILITAS DAN CORPORATE SOCIAL RESPONSIBILITY TERHADAP STOCK RETURNS
}

\author{
Oleh \\ Gusganda Suria Manda \\ Anwar Musadad \\ Meti Nopita \\ Fakultas Ekonomi dan Bisnis - Universitas Singaperbangsa Karawang \\ gusganda_sm@yahoo.co.id \\ DOI Artikel : https://doi.org/10.34308/eqien.v6i2.96
}

\begin{tabular}{l}
\hline Article Info \\
\hline Article History: \\
Received 08 Agustus 2019 \\
Accepted 22 Agustus 2019 \\
Available Online 05 September \\
2019
\end{tabular}

Keyword:

Net Profit Margin (NPM),

Return on Assets (ROA),

Return on Equity (ROE),

Price Earning Ratio (PER),

Corporate Social Responsibility

(CSR), and Stock Return

\begin{abstract}
This research is a quantitative research. The population in this study is companies owned by state-owned companies listed on the Indonesia Stock Exchange for the period 2013-2018, amounting to 20. Sample selection using purposive sampling techniques and obtained 16 companies as research samples. The type of data used is secondary data. The method of library research or library research and documentation is used as a data collection technique. Data analysis methods used in this research are descriptive statistical analysis, classic assumption test, and hypothesis testing.

Data is processed with IBM SPSS Version 22.0 for windows. Based on the results of the study indicate that the variable Net Profit Margin, Return on Equity, and Corporate Social Responsibility have a significant and significant effect on stock returns. Meanwhile, the variable Return on Assets and Price Earning Ratio has no effect on stock returns. The value of the determinant coefficient (R2) produced was 0.444 or $44.4 \%$. This shows that the Net Profit Margin, Return on Equity, and Corporate Social Responsibility variables affect the stock returns of state-owned enterprises listed on the Indonesia stock exchange in the 2013-2018 period that is equal to 44.4\%, while the remaining $55.6 \%$ is influenced by variables other than research.
\end{abstract}

\section{PENDAHULUAN}

Pasar modal merupakan penghubung antara investor dan perusahaan ataupun institusi pemerintah melalui instrumen jangka panjang yang diperjualbelikan, baik obligasi, saham, maupun instrumen lainnya. Salah satu instrumen yang paling populer di pasar modal adalah saham. Karena saham mampu memberikan tingkat keuntungan yang lebih tinggi. Akan tetapi, investasi dalam bentuk saham juga memiliki risiko yang tinggi.

Maka dari itu, sebelum para investor melakukan investasi, sebaiknya para investor mengetahui dan memilih saham mana yang 
akan memberikan keuntungan paling optimal. Dalam memilih saham, para investor memerlukan informasi yang akurat, relevan, dan transparan melalui laporan keuangan yang dipublikasikan di pasar modal agar investor mengetahui perkembangan perusahaan.

Saat ini, aset intangible berupa citra dan tata kelola yang baik memiliki peran yang strategis bagi perusahaan. Perusahaan yang memiliki citra baik dimata masyarakat akan lebih diminati oleh investor karena semakin baik citra yang dimiliki perusahaan, maka semakin tinggi juga kesetiaan konsumen pada perusahaan. Selain kinerja keuangan, tak kalah pentingnya para investor mengetahui mengenai Corporate Social Responsibility (CSR) atau tanggung jawab sosial perusahaan sebelum memilih untuk menginvestasikan dana nya.

Corporate Social Responsibility (CSR) atau tanggung jawab sosial perusahaan di dalam laporan tahunan merupakan kontribusi perusahaan untuk aktivitas lingkungan dan sosial. Pengungkapan CSR yang dilakukan perusahaan diharapkan mampu memberi signal positif dan dapat meningkatkan nilai perusahaan dimata investor. Jika prospek suatu perusahaan sangat kuat dan baik, maka harga saham perusahaan tersebut diperkirakan meningkat pula, dan dengan adanya kenaikan harga saham maka diharapkan return juga akan meningkat.

Program penilaian peringkat kinerja perusahaan (PROPER) tahun 2016-2017 dilakukan evaluasi terhadap 1.786 perusahaan dan hasilnya adalah emas 19 perusahan, hijau 150 perusahaan, biru 1.486 perusahaan, merah 130 perusahaan, dan hitam 1 perusahaan. (Proper.menlh.go.id)

Dari kasus diatas terlihat ternyata masih banyak perusahaan yang mendapatkan nilai hitam, merah, dan biru. Ini menunjukkan bahwa hanya sedikit perusahaan di indonesia yang melakukan program Corporate Social Responsibility (CSR) atau tanggung jawab sosial perusahaan dengan benar. Oleh karena itu, program Corporate Social Responsibility (CSR) atau tanggung jawab sosial perusahaan sangat diperlukan untuk meminimalisir masalah lingkungan dan sosial.

Program CSR didasarkan pada triple bottom line, yaitu people, planet, dan profit. Selain mengejar keuntungan (profit) yang maksimal, perusahaan juga harus memperhatikan dan terlibat dalam pemenuhan kesejahteraan masyarakat (people), dan turut berkontribusi aktif dalam menjaga kelestarian lingkungan (planet). Tanpa terkecuali perusahaan badan usaha milik negara (BUMN) yang sesuai dengan Peraturan Menteri BUMN No. PER-07/MBU/2015 yang kemudian selanjutnya disempurnakan dalam PER09/MBU/2015, maka kebijakan sumber dana program CSR melalui program kemitraan dan bina lingkungan (PKBL) Perseroan mengalami perubahan, yaitu yang semula berasal dari anggaran perseroan yang diperhitungkan sebagai biaya menjadi berasal dari penyisihan laba setelah pajak. Melalui ketentuan tersebut, Perseroan senantiasa menjalankan berbagai program-program CSR baik yang bersifat filantropi maupun program-program yang lebih menekankan pada tujuan-tujuan pengembangan dan peningkatan kualitas hidup masyarakat.

Saat ini ada 17 perusahaan BUMN yang terbagi dalam 9 sektor yang terdaftar di Bursa Efek Indonesia, perusahaan BUMN hampir merata disemua sektor, namun yang terbanyak ada dalam 3 sektor yaitu perbankan, dan kontruksi serta 6 sektor lainnya seperti farmasi, industri logam, energi, semen, sarana dan prasarana angkutan, serta telekomunikasi menyumbangkan paling sedikit. Prestasi dan stagnasi mewarnai semua perusahaan yang ada di Indonesia, tidak terkecuali BUMN. Prestasi menjadi acuan untuk lebih meningkatkan kinerja di masa depan, sementara stagnasi dapat dijadikan bahan evaluasi untuk bergerak dan memperbaiki kinerja menjadi lebih baik.

Perusahaan BUMN memiliki kewajiban untuk melakukan program yang berbentuk kemitraan dengan masyarakat dan bina lingkungan. CSR BUMN sendiri tidak berbeda jauh dengan perusahaan swasta, akan tetapi BUMN lebih kepada pembangunan masyarakat demi kepentingan bersama daripada CSR perusahaan yang dilaksanakan untuk kelangsungan perusahaan sendiri. CSR BUMN difokuskan pada pengembangan potensi dan kondisi ekonomi rakyat untuk menciptakan pembangunan yang merata.

Beberapa peneliti yang menguji pengaruh Net Profit Margin (NPM) terhadap return saham diantaranya adalah Ni Luh Putu Dewi dan Henny Rahyuda (2017) dan Khusniatul Wardah (2017) yang mengungkapkan bahwa NPM berpengaruh positif dan signifikan terhadap return saham. Sedangkan hasil yang berbeda diungkapkan oleh Sami RM MUSALLAM (2018) dan Verawaty,dkk (2015) yang mengatakan bahwa 
NPM tidak berpengaruh signifikan terhadap return saham.

Penelitian mengenai pengaruh Return On Assets (ROA) terhadap return saham dilakukan oleh Luh Kristianti Dewi dan Putu D'yan (2015) yang mengungkapkan bahwa ROA berpengaruh positif dan signifikan terhadap return saham. Penelitian yang dilakukan Ines Tasia Agustin dan Taswan (2017) dan Sami RM MUSALLAM (2018) menghasilkan keputusan bahwa ROA berpengaruh positif dan tidak signifikan terhadap return saham. Sedangkan Ihsan S. Basalama,dkk (2017) dan Sari Octavera, dkk (2016) mengatakan bahwa ROA berpengaruh signifikan terhadap return saham. Hasil tersebut berbeda dengan penelitian yang dilakukan oleh Siti Rahayu, dkk (2015) dan Atiqah (2016) bahwa ROA tidak berpengaruh signifikan terhadap return saham.

Peneliti yang melakukan penelitian mengenai pengaruh Return On Equity (ROE) terhadap return saham salah satunya adalah Trần Nha Ghi (2015) dan Made Reina Candradewi (2016) mengungkapkan bahwa ROE berpengaruh positif dan signifikan terhadap return saham. Sami RM MUSALLAM (2018) menyimpulkan bahwa ROE berpengaruh positif dan tidak signifikan terhadap return saham. Sedangkan hasil yang berbeda diungkapkan oleh Siti Rahayu, dkk (2015), Verawaty,dkk (2015) dan Yudhia Mulya \& Ririn Turisna (2016) bahwa ROE tidak berpengaruh signifikan terhadap return saham.

Beberapa peneliti yang melakukan penelitian tentang pengaruh Price Earning Ratio (PER) terhadap return saham adalah Akwe James Ayuba, et al (2018) dan Sami RM MUSALLAM (2018) yang mengungkapkan bahwa PER berpengaruh positif dan tidak signifikan terhadap return saham. Sedangkan hasil yang berbeda ditunjukkan oleh Verawaty,dkk (2015), Yudhia Mulya \& Ririn Turisna (2016), dan Ni Luh Gde Novitasari (2017) yang mengatakan bahwa PER tidak berpengaruh signifikan terhadap return saham.

Penelitian mengenai Corporate Social Responsibility (CSR) terhadap Return saham dilakukan oleh Luh Kristianti Dewi \& Putu D'yan (2015) dan Ida Bagus Gede \& I Made Karya (2015) menyimpulkan bahwa CSR memiliki pengaruh positif dan signifikan terhadap return saham. Siti Rahayu, dkk (2015), Atiqah (2016) dan Achmad Murdiono (2018) mengungkapkan bahwa CSR memiliki pengaruh signifikan terhadap return saham. Suherman, et al (2016) mengungkapkan bahwa CSR memiliki pengaruh tetapi negatif signifikan terhadap return saham. Sedangkan hasil yang berbeda diungkap oleh Idrianita Anis (2017) dan Nera Marinda (2017) bahwa CSR tidak pengaruh signifikan terhadap return saham.

Penelitian-penelitian terdahulu yang telah dipaparkan diatas memiliki hasil yang berbeda-beda dan tidak konsisten. Memiliki pengaruh atau tidaknya suatu variabel independen terhadap variabel dependen tergantung variabel yang digunakan, tahun penelitian, tempat penelitian serta keadaan yang berbeda.

Karena adanya keterbatasan waktu, tenaga, dana, dan teori-teori. Maka penulis memberi batasan dalam melakukan penelitian serta permasalahan yang diangkat perlu dibatasi variabelnya untuk mempermudah dan menegaskan penulisan laporan penelitian, agar penelitian tersebut dapat dilakukan secara lebih fokus, terarah dan sesuai dengan fokus yang diinginkan. Batasan masalah menyangkut pada hal-hal sebagai berikut :

1. Variabel independen yang akan diteliti adalah corporate social responsibility dan kinerja keuangan yang hanya diproksikan oleh Net Profit Margin, Return On Asset, Return On Equity, dan Price Earning Ratio.

2. Variabel dependen yang akan diteliti yaitu return saham. Return saham yang dimaksudkan dalam penelitian ini adalah return saham berupa capital gain atau capital loss dan dividen yield.

3. Tempat penelitian yang akan dipergunakan hanya perusahaan badan usaha milik negara yang terdaftar di bursa efek indonesia selama periode 2013-2018.

Setelah menetapkan berbagai masalah yang dihadapi maka selanjutnya penulis merumuskan masalah penelitian yang akan dijawab atau memadukan pengetahuannya menjadi suatu perumusan. Ruang lingkup masalah yang akan diteliti ini berdasarkan latar belakang, identifikasi masalah, dan batasan masalah sehingga dapat dirumuskan permasalahannya sebagai berikut :

1. Apakah Net Profit Margin berpengaruh terhadap return saham pada perusahaan badan usaha milik negara yang terdaftar di bursa efek indonesia periode 2013-2018 ? 
2. Apakah Return On Asset berpengaruh terhadap return saham pada perusahaan badan usaha milik negara yang terdaftar di bursa efek indonesia periode 2013-2018 ?

3. Apakah Return On Equity berpengaruh terhadap return saham pada perusahaan badan usaha milik negara yang terdaftar di bursa efek indonesia periode 2013-2018 ?

4. Apakah Price Earning Ratio berpengaruh terhadap return saham pada perusahaan badan usaha milik negara yang terdaftar di bursa efek indonesia periode 2013-2018 ?

Apakah Corporate Social Responsibility (CSR) berpengaruh terhadap return saham pada perusahaan badan usaha milik negara yang terdaftar di bursa efek indonesia periode 2013 2018 ?

\section{KAJIAN PUSTAKA DAN PEGEMBANGAN HIPOTESIS}

\section{Teori Agensi (Agency Theory)}

Jensen dan Meckling (dalam Ni Luh Gde Novitasari, 2017:38) menyatakan bahwa :

"hubungan keagenan adalah sebuah kontrak antara manajer (agent) dan investor (pricipal). Terjadinya konflik kepentingan antara pemilik dan agen karena kemungkinan agen bertindak tidak sesuai dengan kepentingan principal, sehingga memicu biaya keagenan. Sebagai agen, manajer bertanggung jawab secara moral untuk mengoptimalkan keuntungan para pemilik dengan memperoleh kompensasi sesuai dengan kontrak."

Menurut Brigham \& Houston yang dikutip oleh Ida Bagus Gede Waisaka Putra dan I Made Karya Utama (2015:194) bahwa dalam teori keagenan (agency theory), pemilik perusahaan adalah pemegang saham memberikan kekuasaan kepada para manajer untuk membuat keputusan, dimana hal ini menciptakan potensi konflik kepentingan. Sedangkan menurut Yoyo Sudaryo, dkk.(2017:61) bahwa teori agensi adalah kewenangan yang diberikan kepada agen untuk melakukan suatu tindakan dalam hal kepentingan pemilik.

\section{Pasar Modal}

Menurut Darmadji dan Fakhruddin (dalam Ni Luh Putu Dewi,2017:5553). Pasar modal memiliki dua fungsi, yaitu fungsi ekonomi dan fungsi keuangan. Fungsi ekonomi pada pasar modal adalah menyalurkan dana dari investor ke perusahaan sedangkan fungsi keuangannya adalah reward bagi investor atas hasil investasinya berupa keuntungan untuk memaksimalkan kekayaan. Instrumen yang ditawarkan melalui pasar modal adalah instrumen yang berbentuk surat-surat berharga (sekuritas) atau efek. Instrumen itu terbagi atas dua kelompok besar, yaitu instrumen kepemilikan (ekuitas), seperti saham dan instrumen hutang seperti obligasi perusahaan. Menurut Ines Tasia dan Taswan (2017:136) bahwa Pasar modal merupakan jembatan untuk mendistribusikan kesejahteraan kepada masyarakat khususnya kepada pemegang surat berharga perusahaan seperti saham, misalnya pemegang surat berharga akan menerima dividen dan capital gains atau return.

Robert Ang (dalam Ihsan,dkk.2017:1794) juga mengatakan bahwa pasar modal pada aktivitasnya menjalankan fungsi ekonomi dan keuangan, dalam melaksanakan fungsi ekonominya, pasar modal menyediakan media atau tempat dimana pembeli dan penjual bisa bertransaksi atau bernegosiasi pada pertukaran suatu komoditas atau kelompok komoditas, komoditas yang diperjual belikan tersebut adalah modal.

Dapat disimpulkan bahwa pasar modal merupakan jembatan bertransaksi atau menyalurkan dana dari investor kepada perusahaan untuk pendanaan usaha atau pendanaan perusahaan. Sawidji (2015:5) menyatakan bahwa manfaat pasar modal adalah sebagai berikut :

1. Menjadikan Manajemen Profesional

Bagi emiten yang memasuki pasar modal akan terdorong untuk meningkatkan manajemen yang profesional karena perusahaan yang sudah go public akan menjadi sorotan masyarakat dan tentu harus berprestasi baik serta dikelola oleh tenaga-tenaga yang profesional.

2. Solusi Suksesi

Perusahaan yang go public mempunyai peluang untuk bertahan sampai kapan pun. Sehingga dapat diharapkan dari perusahaan-perusahaan kecil akan muncul perusahaan-perusahaan raksasa yang mampu bersaing di pasar global.

3. Alternatif Investasi

Untuk lebih produktif dan menyebar risiko diperlukan tempat investasi lain. Salah satunya diinvestasikan di pasar modal dengan cara membeli saham atau obligasi. 
Meskipun keuntungan yang didapat diiringi risiko yang tidak kecil.

4. Alternatif Sumber Dana

Pendanaan dengan menggunakan pasar modal ini dapat digolongkan sebagai sumber pendanaan yang modern. Disamping itu, dengan memanfaatkan dana dari pasar modal, perusahaan tidak perlu lagi menyediakan dana setiap bulan atau setiap tahun untuk membayar bunga. Sebagai gantinya memang perusahaan harus membayar dividen kepada investor. Namun, dalam jangka panjang perusahaan akan mendapatkan manfaat yang lebih besar diantaranya bisa menggunakan dana yang jauh lebih panjang dan mendapatkan dana yang lebih besar.

Menurut Khusniatul Wardah (2017:40) bahwa Laporan keuangan merupakan bentuk pertanggungjawaban perusahaan terhadap para investor dan masyarakat pada umumnya. Dalam hal ini, perusahaan dapat menjadi pihak yang memberikan informasi mengenai kondisi perusahaan dan juga sebagai pihak yang dapat dievaluasi berdasarkan laporan keuangan.

Menurut Hery (2015:19) bahwa laporan keuangan pada dasarnya adalah hasil dari proses akuntansi yang dapat digunakan sebagai alat untuk mengkomunikasikan data keuangan atau aktivitas perusahaan kepada pihak-pihak yang berkepentingan.

Hery (2015:19) juga menyatakan bahwa :

"Tujuan khusus laporan keuangan adalah menyajikan secara wajar dan sesuai dengan prinsip akuntansi yang berlaku umum mengenai posisi keuangan, hasil usaha dan perubahan lain dalam posisi keuangan."

Menurut PSAK 1 revisi (revisi 2009) bahwa tujuan laporan keuangan adalah sebagai berikut

1. Memberikan informasi yang menyangkut posisi keuangan, kinerja serta perubahan posisi keuangan suatu entitas yang bermanfaat bagi sejumlah pemakai dalam pengambilan keputusan ekonomi.

2. Menunjukkan apa yang telah dilakukan manajemen dan pertanggung jawaban sumber daya yang dipercaya kepadanya.

3. Memenuhi kebutuhan bersama sebagian besar pemakai.

4. Menyediakan pengaruh keuangan dari kejadian di masa lampau.

Fungsi utama laporan keuangan bagi pihak eksternal menurut dwi martani ,dkk (2016:33) adalah sebagai berikut :
1. Pemegang saham, informasi untuk menilai enttitas dan kemampuan perusahaan dalam membayar dividen di masa mendatang.

2. Calon investor, informasi untuk menilai apakah dana yang akan mereka investasikan layak atau tidak. Karena penanaman modal memiliki risiko yang sangat tinggi.

3. Kreditur, informasi untuk menilai kemampuan perusahaan dalam pengembalian hutang pokok dan bunga saat jatuh tempo

4. Supplier, informasi untuk menilai kemampuan perusahaan dalam melunasi atau membayar tagihan penjualan tepat waktu

5. Pemerintah, informasi mengenai bagaimana alokasi sumber daya, kebijakan pajak dan data pendapatan nasional.

6. Masyarakat, informasi untuk menilai perkembangan kemakmuran dan tren suatu entitas.

\section{Kinerja Keuangan}

Menurut Khusniatul Wardah (2017:40) kinerja keuangan merupakan gambaran dari kondisi keuangan perusahaan yang dapat dianalisis menggunakan perhitungan keuangan seperti rasio, sehingga dengan hasil analisis tersebut dapat diketahui kondisi keuangan sebuah perusahaan, tingkat kesehatan, dan manajemen perusahaan guna mencerminkan prestasi kerja dalam periode waktu tertentu.

Menurut Cornelia Erviana dan Andreas Lako (2018:188) kinerja keuangan merupakan hasil atau prestasi yang telah dicapai oleh manajemen perusahaan dalam mengelola aset perusahaan secara efektif dalam periode tertentu yang mencerminkan tingkat kesehatan perusahaan tersebut.

SahamMenurut Ang (dalam Khusniatul,2017:38) bahwa saham adalah surat berharga sebagai bukti penyertaan atau pemilikan individu maupun institusi dalam suatu perusahaan. Sedangkan menurut Khusniatul Wardah (2017:38) Saham merupakan sebuah surat berharga yang menjadi bukti kepemilikan dari suatu perusahaan melalui pembelian saham perusahaan, maka seorang investor berhak mendapatkan keuntungan melalui pembagian deviden. 
Instrumen dipasar modal yang paling populer diperjualbelikan adalah saham. Saham merupakan surat berharga yang menjadi bukti kepemilikan dari suatu perusahaan, maka investor berhak mendapatkan keuntungan atas dana yang telah ditanamkan oleh investor.

\section{Return Saham}

Menurut Khusniatul Wardah (2017:39)

Return merupakan hasil yang diperoleh dari suatu investasi yang telah ditanamkan oleh seorang investor pada suatu perusahaan, sedangkan return total saham merupakan return keseluruhan dari suatu investasi dalam periode waktu tertentu.

Menurut Corrado dan Jodan (dalam Cornelia dan Lako,2018:186) bahwa return saham adalah tingkat pengembalian baik keuntungan maupun kerugian yang akan diterima oleh investor yang telah berinvestasi. Trần Nha Ghi (2015:734) juga mengatakan bahwa "Stock return is a crucial issue as well as the strategical target to achieve by shareholders who wish to maximine it." Return saham adalah masalah penting serta target strategis untuk dicapai oleh pemegang saham yang ingin memaksimalkannya.

Menurut Ni Luh Gde (2017:34) mengatakan bahwa return saham adalah pendapatan yang dinyatakan dalam persentase dari modal awal investasi. Pendapatan investasi dalam saham ini meliputi keuntungan jual beli saham, dimana jika untung disebut capital gain dan jika rugi disebut capital loss, selain itu investor juga akan menerima dividen tunai setiap tahunnya

\section{Laporan Keuangan}

bentuk

pertanggungjawaban perusahaan terhadap para investor dan masyarakat pada umumnya. Dalam hal ini, perusahaan dapat menjadi pihak yang memberikan informasi mengenai kondisi perusahaan dan juga sebagai pihak yang dapat dievaluasi berdasarkan laporan keuangan.

Menurut Hery (2015:19) bahwa laporan keuangan pada dasarnya adalah hasil dari proses akuntansi yang dapat digunakan sebagai alat untuk mengkomunikasikan data keuangan atau aktivitas perusahaan kepada pihak-pihak yang berkepentingan.

bahwa :

Hery (2015:19) juga menyatakan

"Tujuan khusus laporan keuangan adalah menyajikan secara wajar dan sesuai dengan prinsip akuntansi yang berlaku umum mengenai posisi keuangan, hasil usaha dan perubahan lain dalam posisi keuangan."

Menurut PSAK 1 revisi (revisi 2009) bahwa tujuan laporan keuangan adalah sebagai berikut :

1. Memberikan informasi yang menyangkut posisi keuangan, kinerja serta perubahan posisi keuangan suatu entitas yang bermanfaat bagi sejumlah pemakai dalam pengambilan keputusan ekonomi.

2. Menunjukkan apa yang telah dilakukan manajemen dan pertanggung jawaban sumber daya yang dipercaya kepadanya.

3. Memenuhi kebutuhan bersama sebagian besar pemakai

4. Menyediakan pengaruh keuangan dari kejadian di masa lampau.

Hipotesis

Hipotesis penelitian merupakan jawaban sementara peneliti sebelum dilakukan pengujian hipotesis. Berdasarkan kerangka pemikiran dan hasil dari beberapa penelitian terdahulu, maka hipotesis dapat dirumuskan sebagai berikut:

H1 : Net profit margin berpengaruh terhadap return saham.

$\mathrm{H} 2$ : Return on asset berpengaruh terhadap return saham.

H3 : Return on equity berpengaruh terhadap return saham.

$\mathrm{H} 4 \quad$ : Price earning ratio berpengaruh terhadap return saham.

H5 : Corporate social responsibility berpengaruh terhadap return saham.

\section{METODE PENELITIAN}

Metode Penelitian yang digunakan penulis adalah mengumpulkan data historis dan melakukan pengamatan yang berkaitan dengan masalah yang akan diteliti sehingga akan memperoleh data untuk melengkapi penyusunan laporan penelitian. Dari data yang diperoleh tersebut dianalisis dengan dasardasar teori yang telah dipelajari sehingga memperoleh gambaran dan dapat menarik kesimpulan dari masalah yang diteliti.

Pendekatan dalam penelitian ini menggunakan pendekatan kuantitatif. Menurut Sujarweni (2016:2) penelitian metode kuantitatif adalah jenis penelitian yang menghasilkan penemuan-penemuan yang dapat dicapai (diperoleh) dengan menggunakan prosedur-prosedur statistik atau cara-cara lain dari kuantifikasi (pengukuran). 
Berdasarkan pemaparan diatas, maka dapat dikemukakan definisi konseptual dari masing-masing variabel yang akan diteliti sebagai berikut :

1. Kinerja Keuangan

Kinerja keuangan merupakan suatu analisis yang menggambarkan kondisi keuangan perusahaan dengan alat-alat analisis keuangan, sehingga dapat diketahui baik buruknya kondisi keuangan perusahaan yang mencerminkan prestasi kerja dalam periode tertentu. Alat analisis yang digunakan dalam penelitian ini sebagai berikut :

a. Net Profit Margin (NPM)

b. Net Profit Margin (NPM) merupakan rasio yang menggambarkan kemampuan perusahaan dalam menghasilkan keuntungan dari setiap penjualan yang dilakukan. Menurut Monica,dkk (2015:142) Net Profit Margin adalah rasio yang digunakan untuk mengukur kemampuan perusahaan dalam menghasilkan laba bersih sebelum pajak (net income) ditinjau dari sudut pendapatan operasinya. Rasio ini menunjukkan persentase keuntungan bersih yang diperoleh perusahaan untuk setiap pendapatan karena memasukkan semua unsur pendapatan laba.

c. Return On Asset (ROA)

d. Return On Asset adalah rasio yang menunjukkan kemampuan suatu perusahaan dalam menghasilkan laba dari seluruh aset yang dimiliki. Penilaian ROA tersebut dapat menunjukkan bahwa kinerja keuangan mengalami penurunan dan itu berarti kinerja keuangan perusahaan kurang menguntungkan karena tingkat pengembaliannya lebih rendah atas aset yang diinvestasikan (Menurut Monica,dkk.2015:142)

\section{e. Return On Equity (ROE)}

Rasio ini juga merupakan ukuran profitabilitas bagi para pemegang saham untuk menilai baik buruknya kinerja keuangan perusahaan. Monica,dkk (2015:142) menjelaskan bahwa Rasio ini menunjukkan berapa persen diperoleh laba bersih bila diukur dari modal pemilik, yakni berguna untuk mengetahui besarnya kembalian yang diberikan oleh perusahaan untuk setiap satu Rupiah modal dari pemilik.

f. Price Earning Ratio (PER)

Rasio digunakan untuk mengukur harga saham relatif terhadap laba nya dan untuk mengetahui tingkat risiko dan pertumbuhan perusahaan di masa depan. PER merupakan rasio perbandingan antara harga saham dengan pendapatan setiap lembar saham dan semakin tinggi PER menunjukkan prospek harga saham suatu perusahaan dinilai semakin tinggi oleh investor terhadap pendapatan per lembar sahamnya (Ni Luh Gde, 2017:40).

2. Corporate social responsibility (CSR)

Corporate social responsibility atau tanggung jawab sosial perusahaan merupakan program yang akan dilakukan perusahaan untuk meminimalisir masalah lingkungan dan sosial masyarakat sekitar perusahaan. Menurut Cornelia dan Lako (2018:188) Corporate social responsibility merupakan hasil atau tingkat keberhasilan yang telah dicapai perusahaan dalam mengikuti aturan pemerintah yang terkandung dalam undang-undang akan memberikan dampak yang positif terhadap masyarakat sekitar baik dari segi lingkungan maupun pembangunan berkelanjutan.

3. Return saham

Dalam penelitian ini variabel terikat atau variabel dependen yang digunakan yaitu return saham. Menurut Khusniatul Wardah (2017:39) Return merupakan hasil yang diperoleh dari suatu investasi yang telah ditanamkan oleh seorang investor pada suatu perusahaan, sedangkan return total saham merupakan return keseluruhan dari suatu investasi dalam periode waktu tertentu.

Populasi dalam penelitian ini adalah Badan Usaha Milik Negara yang terdaftar Bursa Efek Indonesia selama periode 2013-2018.

Menurut Sujarweni (2016:4) sampel adalah bagian dari sejumlah karakteristik yang dimiliki oleh populasi yang digunakan untuk penelitian. Apabila populasinya besar atau banyak, peneliti tidak mungkin menjadikan semua populasi menjadi sampel karena nanti kesimpulannya dapat diberlakukan hanya untuk populasi, sehingga perlu dilakukan pengambilan sampel. Menurut Sugiyono (2018:81) teknik sampling merupakan teknik untuk pengambilan sampel. 
Teknik sampling dibagi menjadi 2 (dua) yaitu probability sampling dan non probability sampling, dalam penelitian ini menggunakan teknik probability sampling. Menurut sujarweni (2016:5) bahwa non probability sampling adalah pengambilan sampel yang tidak memberikan peluang atau kesempatan yang sama bagi setiap unsur atau anggota populasi untuk dipilih menjadi sampel. Adapun cara pengambilan sampel dalam penelitian ini menggunakan sampling purposive, yaitu teknik penentuan sampel dengan pertimbangan atau kriteria-kriteria tertentu.

\section{HASIL DAN PEMBAHASAN}

Analisis data dan pengujian terhadap masingmasing hipotesis dalam penelitian ini menggunakan program IBM SPSS (Statistical Package for Social Science) Version 22 for Windows.

Analisis statistik deskriptif digunakan untuk memberikan gambaran atau deskripsi tentang data setiap variabel penelitian yang digunakan dalam penelitian. Dalam penelitian ini terdapat variabel kinerja keuangan, corporate social responsibility dan Return saham. Ketiga variabel tersebut dapat diketahui jumlah sampel, nilai minimum, maximum, mean dan standar deviasinya dari data yang telah diolah menggunakan program SPSS versi 22 yang disajikan dalam tabel 4.1 sebagai berikut :

\section{Tabel .1}

Analisis Statistik Deskriptif

\begin{tabular}{|l|r|r|r|r|r|}
\hline \multicolumn{7}{|c|}{ Kescrangan } & \multicolumn{1}{|c|}{ N } & \multicolumn{1}{c|}{ Minimum } & Maximum & \multicolumn{1}{c|}{ Mean } & $\begin{array}{c}\text { Std. } \\
\text { Deviation }\end{array}$ \\
\hline Net Profit Margin & 78 & $-24,70$ & 27,91 & 7,3340 & 10,03585 \\
\hline Return on Asset & 78 & $-11,48$ & 19,40 & 4,4571 & 5,94470 \\
\hline Return on Equity & 78 & $-38,84$ & 35,27 & 9,9848 & 12,56510 \\
\hline Price Earning Ratio & 78 & $-83,57$ & 253,33 & 22,1058 & 46,66195 \\
\hline $\begin{array}{l}\text { Corporate Social } \\
\text { Responsibility }\end{array}$ & 78 &, 12 &, 48 &, 2659 &, 08164 \\
\hline Return Saham & 78 &,- 69 & 38,27 & 1,6838 & 5,74210 \\
\hline Valid N (listwise) & 78 & & & & \\
\hline
\end{tabular}

Berdasarkan hasil output SPSS pada tabel.1, maka diperoleh hasil sebagai berikut :

\section{Net Profit Margin (NPM)}

Jumlah pengamatan pada perusahaan BUMN yang terdaftar di bursa efek indonesia periode 2013-2018 dalam penelitian ini sebanyak 78 data. Hasil statistik deskriptif dari variabel independen Net Profit Margin (NPM) memiliki nilai minimum sebesar -24.70 , nilai maximum sebesar 27.91, nilai rata-rata (mean) sebesar
7,3340 dan standar deviasinya sebesar 10,03585 .

2. Return on Asset (ROA)

Jumlah pengamatan pada perusahaan BUMN yang terdaftar di bursa efek indonesia periode 2013-2018 dalam penelitian ini sebanyak 78 data. Hasil statistik deskriptif dari variabel independen Return on Asset (ROA) memiliki nilai minimum sebesar -11.48 , nilai maximum sebesar 19.40, nilai rata-rata (mean) sebesar 4.4571 dan standar deviasinya sebesar 5.94470 .

3. Return on Equity (ROE)

Jumlah pengamatan pada perusahaan BUMN yang terdaftar di bursa efek indonesia periode 2013-2018 dalam penelitian ini sebanyak 78 data. Hasil statistik deskriptif dari variabel independen Return on Equity (ROE) memiliki nilai minimum sebesar -38.84 , nilai maximum sebesar 35.27, nilai rata-rata (mean) sebesar 9.9848 dan standar deviasinya sebesar 12.56510 .

4. Price Earning Ratio (PER)

Jumlah pengamatan pada perusahaan BUMN yang terdaftar di bursa efek indonesia periode 2013-2018 dalam penelitian ini sebanyak 78 data. Hasil statistik deskriptif dari variabel independen Price Earning Ratio (PER) memiliki nilai minimum sebesar -83.57 , nilai maximum sebesar 253.33, nilai rata-rata (mean) sebesar 22.1058 dan standar deviasinya sebesar 46.66195.

5. Corporate Social Responsibility (CSR)

Jumlah pengamatan pada perusahaan BUMN yang terdaftar di bursa efek indonesia periode 2013-2018 dalam penelitian ini sebanyak 78 data. Hasil statistik deskriptif dari variabel independen Corporate Social Responsibility (CSR) memiliki nilai minimum sebesar 0.12 , nilai maximum sebesar 0.48 , nilai rata-rata (mean) sebesar 0.2659 dengan standar deviasinya sebesar 0.08164 .

6. Return Saham

Jumlah pengamatan pada perusahaan BUMN yang terdaftar di bursa efek indonesia periode 2013-2018 dalam penelitian ini sebanyak 78 data. Hasil statistik deskriptif dari variabel dependen Return Saham memiliki nilai minimum sebesar -0.69, nilai maximum sebesar 38.27, 
nilai rata-rata (mean) sebesar 1.6838 dan standar deviasinya sebesar 5.74210 .

Analisis Regresi Linier Berganda Analisis ini digunakan untuk mengetahui nilai dari variabel dependen apabila nilai variabel independen mengalami kenaikan atau penurunan. Untuk mengetahui arah hubungan masing-masing variabel antara variabel independen dengan variabel dependen berhubungan positif atau negatif.

Tabel.2

Hasil Analisis Regresi Linier Berganda Coefficients $^{\mathbf{a}}$

\begin{tabular}{|c|c|c|c|c|c|}
\hline \multirow[b]{2}{*}{ Model } & \multicolumn{2}{|c|}{$\begin{array}{l}\text { Unstandardized } \\
\text { Coefficients }\end{array}$} & \multirow{2}{*}{$\begin{array}{c}\text { Standardized } \\
\text { Coefficients } \\
\text { Beta }\end{array}$} & \multirow[b]{2}{*}{$\mathrm{t}$} & \multirow[b]{2}{*}{ Sig. } \\
\hline & B & $\begin{array}{l}\text { Std. } \\
\text { Error }\end{array}$ & & & \\
\hline 1 (Constant) & ,604 & ,442 & & 1,368 &, 177 \\
\hline NPM & , 108 & ,030 & ,886 & 3,616 & ,001 \\
\hline ROA &,- 096 & ,052 &,- 460 & $-1,846$ &, 070 \\
\hline ROE & ,054 & ,011 & ,475 & 4,810 & ,000 \\
\hline PER &,- 001 & ,001 &,- 086 &,- 879 & ,383 \\
\hline CSR & $-3,478$ & 1,461 &,- 232 & $-2,380$ & ,021 \\
\hline
\end{tabular}

Sumber : data diolah penulis, 2019.

Berdasarkan tabel 4.8 diatas, menunjukkan bahwa model regresi untuk memperkirakan Return saham yang dipengaruhi oleh NPM, ROA, ROE, PER, dan CSR. Bentuk regresi linier berganda nya sebagai berikut :

Return saham $=0.604+0.108 \mathrm{NPM}-0.096 \mathrm{ROA}+0.054 \mathrm{ROE}-0.001 \mathrm{PER}$ $-3.478 \mathrm{CSR}+\mathrm{e}$

Persamaan regresi diatas dapat dianalisis sebagai berikut :

1. Konstanta $(\alpha)$ sebesar 0.604 mempunyai arti apabila semua variabel independen yaitu NPM, ROA, ROE, PER, dan CSR sama dengan nol maka Return saham nilainya sebesar 0.604.

2. Nilai koefisien regresi variabel NPM bernilai positif yang menunjukkan adanya hubungan yang searah antara NPM dengan Return saham. Koefisien regresi NPM sebesar 0.108 artinya apabila NPM meningkat maka Return saham juga akan meningkat sebesar 0.108 dengan asumsi variabel independen lainnya bernilai tetap.

3. Nilai koefisien regresi variabel ROA bernilai negatif yang menunjukkan tidak adanya hubungan yang searah antara ROA dengan Return saham. Koefisien regresi ROA sebesar -0.096 artinya apabila ROA meningkat maka akan menurunkan nilai
Return saham sebesar 0.096 dengan asumsi variabel independen lainnya bernilai tetap.

4. Nilai koefisien regresi variabel ROE bernilai positif yang menunjukkan adanya hubungan yang searah antara ROE dengan Return saham. Koefisien regresi ROE sebesar 0.054 artinya apabila ROE mengalami peningkatan, maka akan menaikkan Return saham sebesar 0.054 dengan asumsi variabel independen lainnya bernilai tetap.

5. Nilai koefisien regresi variabel PER bernilai negatif yang menunjukkan tidak adanya hubungan yang searah antara PER dengan Return saham. Koefisien regresi PER sebesar -0.001 artinya apabila PER mengalami kenaikan, maka akan menurunkan Return saham sebesar 0.001 dengan asumsi variabel independen lainnya bernilai tetap.

6. Nilai koefisien regresi variabel CSR bernilai negatif yang menunjukkan tidak adanya hubungan yang searah antara CSR dengan Return saham. Koefisien regresi CSR sebesar -3.478 artinya apabila CSR mengalami kenaikan, maka akan menurunkan nilai Return saham sebesar 3.478 dengan asumsi variabel independen lainnya bernilai tetap.

Koefisien determinasi digunakan untuk mengukur seberapa besar variabel independen untuk menjelaskan variabel dependen dalam model regresi. Hasil dari koefisien determinan dapat dilihat pada tabel berikut :

Tabel 4.10

Koefisien Determinan $\left(\mathbf{R}^{2}\right)$ Model Summary ${ }^{b}$

\begin{tabular}{|l|c|r|r|r|}
\hline Model & $\mathrm{R}$ & R Square & $\begin{array}{c}\text { Adjusted } \\
\text { R Square }\end{array}$ & \multicolumn{1}{c|}{$\begin{array}{c}\text { Std. Error of the } \\
\text { Estimate }\end{array}$} \\
\hline 1 &, $700^{\mathrm{a}}$ &, 489 &, 444 & \multicolumn{1}{c|}{, 94810} \\
\hline
\end{tabular}

Sumber : data diolah penulis, 2019 .

Berdasarkan tabel 4.10 diatas, nilai koefisien determinasi $\left(\mathrm{R}^{2}\right)$ yang dilihat dari Adjusted $R$ Square yaitu Net Profit Margin (NPM), Return on Equity (ROE), dan Corporate Social Responsibility (CSR) sebesar 0.444 atau $44.4 \%$. Artinya, $44.4 \%$ variabel Return saham dapat dipengaruhi oleh variabel NPM, ROE, dan CSR. Sedangkan sisanya 55.6\% dijelaskan oleh variabel lain yang tidak penulis libatkan dalam penelitian ini.

\section{Pengaruh Net Profit Margin terhadap Return saham}


Berdasarkan hasil pengujian, hipotesis pertama diterima karena nilai $\mathrm{t}_{\text {Tabel }}$ lebih kecil daripada $\mathrm{t}_{\text {hitung }}(1.985<3.616)$, demikian pula dengan nilai signifikansi yang nilainya lebih kecil dari tingkat signifikansi yang telah ditetapkan $(0.001<0.05)$. Sehingga disimpulkan bahwa Net Profit Margin (NPM) memiliki pengaruh dan signifikan terhadap Return saham. Hasil analisis tersebut kontras dengan penelitian yang dilakukan oleh Sami RM MUSALLAM (2018) dan Verawaty,dkk (2015). Akan tetapi hasil tersebut sejalan dengan hasil penelitian yang dilakukan oleh Ni Luh Putu Dewi dan Henny Rahyuda (2017) serta Khusniatul Wardah (2017) yang menemukan bahwa NPM berpengaruh positif dan signifikan terhadap Return saham.

\section{Pengaruh Return on Asset terhadap Return saham}

Berdasarkan hasil pengujian, hipotesis kedua ditolak karena nilai - $t_{\text {Tabel }}$ lebih besar daripada $\mathrm{t}_{\text {hitung }}(-1.985>-1.846)$, demikian pula dengan nilai signifikansi yang nilainya lebih besar dari tingkat signifikansi yang telah ditetapkan (0.070 > 0.05). Sehingga disimpulkan bahwa Return on Asset (ROA) tidak memiliki pengaruh terhadap Return saham. Hasil analisis tersebut kontras dengan penelitian Ihsan S. Basalama,dkk (2017) dan Sari Octavera,dkk (2016). Akan tetapi sejalan dengan penelitian yang dilakukan oleh Siti Rahayu, dkk (2015) dan Atiqah (2016) yang menemukan bahwa ROA tidak berpengaruh signifikan terhadap Return saham.

\section{Pengaruh Return on Equity (ROE) terhadap Return saham}

Berdasarkan hasil pengujian, hipotesis ketiga diterima karena nilai $\mathrm{t}_{\text {Tabel }}$ lebih kecil daripada $\mathrm{t}_{\text {hitung }}(1.985<4.810)$, demikian pula dengan nilai signifikansi yang nilainya lebih kecil dari tingkat signifikansi yang telah ditetapkan $(0.000>0.05)$. Sehingga disimpulkan bahwa Return on Equity (ROE) memiliki pengaruh dan signifikan terhadap Return saham. Hasil analisis tersebut kontras dengan penelitian Siti Rahayu, dkk (2015), Verawaty,dkk (2015), serta Yudhia Mulya \& Ririn Turisna (2016). Akan tetapi sejalan dengan penelitian yang dilakukan oleh Trần Nha Ghi (2015) dan Made Reina Candradewi (2016) mengungkapkan bahwa ROE berpengaruh positif dan signifikan terhadap Return saham.

\section{Pengaruh Price Earning Ratio (PER) terhadap Return saham}

Berdasarkan hasil pengujian, hipotesis keempat ditolak karena nilai $\mathrm{t}_{\text {Tabel }}$ lebih besar daripada $t_{\text {hitung }}(1.985>-0.879)$, demikian pula dengan nilai signifikansi yang nilainya lebih besar dari tingkat signifikansi yang telah ditetapkan $(0.383$ > 0.05). Sehingga disimpulkan bahwa Price Earning Ratio (PER) tidak memiliki pengaruh terhadap Return saham. Hasil analisis tersebut kontras dengan Akwe James Ayuba, et al (2018) dan Sami RM MUSALLAM (2018). Akan tetapi sejalan dengan hasil penelitian yang dilakukan oleh Verawaty,dkk (2015), Yudhia Mulya \& Ririn Turisna (2016), dan Ni Luh Gde Novitasari (2017) yang mengungkapkan bahwa PER tidak berpengaruh dan tidak signifikan terhadap Return saham.

\section{Pengaruh Corporate Social Responsibility (CSR) terhadap Return saham}

Berdasarkan hasil pengujian, hipotesis kelima diterima karena nilai - $\mathrm{t}_{\text {Tabel }}$ lebih kecil daripada - $t_{\text {hitung }}(-1.985<-2.238)$, demikian pula dengan nilai signifikansi yang nilainya lebih kecil dari tingkat signifikansi yang telah ditetapkan (0.021 > 0.05). Sehingga disimpulkan bahwa Corporate Social Responsibility (CSR) memiliki pengaruh dan signifikan terhadap Return saham. Hasil analisis tersebut kontras dengan penelitian Suherman, et al (2016) dan Idrianita Anis (2017). Akan tetapi sejalan dengan penelitian yang dilakukan oleh Siti Rahayu, dkk (2015), Atiqah (2016) dan Achmad Murdiono (2018) mengungkapkan bahwa CSR memiliki pengaruh signifikan terhadap return saham.

\section{SIMPULAN DAN SARAN}

1. Variabel Net Profit Margin (NPM) berpengaruh dan signifikan terhadap Return saham pada perusahaan BUMN yang terdaftar di bursa efek indonesia periode 2013-2018. Hal ini menunjukkan bahwa semakin tinggi nilai NPM, maka Return saham yang akan diterima oleh investor juga tinggi sehingga berpengaruh terhadap peningkatan Return saham perusahaan dan dapat dijadikan pertimbangan investor ataupun calon investor dalam keputusan investasi pada perusahaan BUMN.

2. Variabel Return on Asset (ROA) tidak berpengaruh signifikan terhadap Return saham pada perusahaan BUMN yang terdaftar di bursa efek indonesia periode 
2013-2018. Hal ini menunjukkan bahwa semakin tinggi nilai ROA, tidak berpengaruh terhadap peningkatan Return saham perusahaan dan tidak dapat dijadikan pertimbangan investor ataupun calon investor dalam keputusan investasi pada perusahaan BUMN.

3. Variabel Return on Equity (ROE) berpengaruh terhadap Return saham pada perusahaan BUMN yang terdaftar di bursa efek indonesia periode 2013-2018. Hal ini menunjukkan bahwa semakin tinggi nilai ROE, maka Return saham yang akan diterima oleh investor juga tinggi sehingga berpengaruh terhadap peningkatan Return saham perusahaan dan dapat dijadikan pertimbangan investor ataupun calon investor dalam keputusan investasi pada perusahaan BUMN.

4. Variabel Price Earning Ratio (PER) tidak berpengaruh terhadap Return saham pada perusahaan BUMN yang terdaftar di bursa efek indonesia periode 2013-2018. Hal ini menunjukkan bahwa semakin tinggi nilai PER, tidak berpengaruh terhadap peningkatan Return saham perusahaan dan tidak dapat dijadikan pertimbangan investor ataupun calon investor dalam keputusan investasi pada perusahaan BUMN.

5. Variabel Corporate Social Responsibility (CSR) berpengaruh dan signifikan terhadap Return saham pada perusahaan BUMN yang terdaftar di bursa efek indonesia periode 2013-2018. Hal ini menunjukkan bahwa semakin banyak perusahaan yang melakukan pengungkapan CSR, maka semakin berpengaruh pula terhadap peningkatan Return saham perusahaan dan dapat dijadikan pertimbangan investor ataupun calon investor dalam keputusan investasi pada perusahaan BUMN.

\section{Saran}

Bagi lembaga perusahaan diharapkan melakukan program Corporate Social Responsibility (CSR) atau tanggung jawab sosial perusahaan dan lebih memperhatikan pengungkapan CSR yang bermanfaat untuk perusahaan itu sendiri dalam waktu jangka panjang serta mengungkapkannya secara kontinu melalui laporan tahunan maupun media, agar manfaatnya dirasakan dan diketahui oleh investor dan calon investor.
Perusahaan juga sebaiknya meningkatkan kinerja keuangan perusahaan dengan cara meningkatkan laba bersih setelah pajak setiap tahunnya dan memberikan infromasi mengenai kinerja keuangan yang objektif dan relevan sehingga persepsi dan kepercayaan investor maupun calon investor terhadap saham milik pemerintah dimasa depan dapat dijaga dengan baik dan minat investor maupun calon investor akan semakin bertambah sehingga permintaan saham dan harga saham milik pemerintah pun meningkat. Secara otomatis Return saham pun mengikuti peningkatannya.

\section{REFERENSI}

Agustin, Ines Tasia dan Taswan.2017. Pengaruh konsentrasi kepemilikan, struktur modal, likuiditas, dan profitabilitas terhadap return saham. Jurnal Bisnis dan Ekonomi (JBE). Vol 24 No 2. Hal 136 - 149. ISSN : 14123126 .

Anis,Idrianita.2017. Pengaruh pengungkapan csr terhadap pelaporan pajak agresif, dan pengaruhnya terhadap return saham. JURNAL AKUNTANSI RISET. Vol 9 No 1. Hal 73-100. ISSN : 2541-0342.

Atiqah. 2016. Pengaruh Pengungkapan Tanggung Jawab Sosial Perusahaan Terhadap Tingkat Pengembalian Saham. Jurnal Ilmu Akuntansi Vol 9 No 2. Hal 215230. ISSN : 2461-1190.

Ayuba, Akwe James. et al. 2018. Effects of Firm Level Attributes on Stock Returns in Nigeria. International Journal of Finance and Accounting. Vol 7 No 4. Hal : 122-131. DOI: 10.5923/j.ijfa.20180704.04.

Basalama, Ihsan S., Sri Murni, dan Jacky.2017. Pengaruh current ratio, DER dan ROA terhadap return saham pada perusahaan automotif dan komponen periode 2013-2015. Jurnal EMBA. Vol 5 No 2. Hal 1793-1803. ISSN : 2303-1174.

Candradewi,Made Reina.2016. Pengaruh kinerja keuangan terhadap return saham Pada perusahaan LQ45 di BEI: analisis regresi data panel. E-Jurnal Ekonomi dan Bisnis Universitas Udayana. Vol 5 No 7. 
Hal: 2091-2122. ISSN : 23373067.

Cornelia dan Lako.2018. Faktor-faktor yang mempengaruhi kinerja harga saham dengan csr sebagai variabel pemoderasi. Jurnal Akuntansi Bisnis. Vol 16 No 2. Hal 185-208. ISSN : 2541-5204.

Dewi, Ni Luh Putu dan Henny Rahyuda.2017. Pengaruh kinerja keuangan terhadap return saham perusahaan perbankan di bursa efek indonesia (BEI). E-Jurnal Manajemen Unud. Vol 6 No 10. Hal 5552-5579. ISSN : 23028912.

Dewi,Luh Kristianti Dan Putu D'yan Yaniartha Sukartha. nn1 r r.t......... Kinerja Keu

Saham

Pengungkapan Corporate Social Responsibility. E-Jurnal Akuntansi Universitas Udayana. Vol 12 No $3 \mathrm{Hal}:$ 516-529. ISSN: 2302-8556.

Ghi,Trần Nha.2015. The impact of capital structure and financial performance on stock returns of the firms in hose. International Journal of Information Research and Review. Vol 2 Issue 06. Hal 734-737. ISSN: 2349-9141.

Khafa,Lais dan Herry Laksito. 2015. Pengaruh csr, ukuran perusahaan, leverage, dan keputusan investasi pada kinerja keuangan perusahaan dan nilai perusahaan. Diponegoro journal of accounting. Vol 4 No 4. Hal : 1-13. ISSN : 2337-3806.

Machdar, Nera Marinda. 2017. Corporate Financial Performance, Corporate Environmental Performance, Corporate Social Performance And Stock Return. Jurnal manajemen dan kewirausahaan. Vol 19 No 2. Hal : 118-124. DOI: 10.9744/jmk.19.2.118-124

Monica,dkk.2015. Analisis rasio likuditas, leverage, dan profitabilitas untuk menilai kinerja Keuangan pada perum pegadaian jakarta. Jurnal EMBA. Vol 3 No1. Hal 136-144. ISSN : 2303-1174.
Mulya, Yudhia dan Ririn Turisna.2016. Pengaruh kinerja keuangan terhadap return saham pada perusahaan sub sektor otomotif yang terdaftar di bursa efek indonesia. Jurnal Ilmiah Manajemen Fakultas Ekonomi. Vol 2 No 1. Edisi 2, Hal. 41-52. ISSN : 2502-5678.

Murdiono,Achmad.2018. The Influence of Corporate Social Responsibility (CSR) Disclosure Towards Company Stock Return Moderated By Profit. The First International Research Conference on Economics and Business. Hal 457-466. DOI 10.18502/kss.v3i3.1903.

Sami RM.2018. Exploring the Relationship between Financial Ratios and Market Stock Returns. Eurasian Journal of Business and Economics. Vol 11 No 21. Hal 101-116. DOI https://doi.org/10.17015/ejbe.201 8.021.06.

Novitasari, Ni Luh Gde. 2017. Pengaruh corporate governance dan faktor fundamental terhadap return saham pada perusahaan manufaktur yang terdaftar di bursa efek indonesia. Jurnal Kumpulan Riset Akuntansi. Vol 9 No 1. Hal 36-49. ISSN: 23018879.

Octavera,Sari.dkk.2016. Analisis pengaruh penilaian kinerja keuangan dengan menggunakan metode tradisional (DER,ROA) dan Metode konsep baru (EVA) terhadap return saham (studi kasus pada perusahaan industri keuangan Non bank yang listing di BEI pada tahun 2010-2014). Jurnal ekonomi \& bisnis dharma andalas. Vol 18 No 1. Hal 138159. ISSN : 1693-3273.

Octavera, Sari dan Febri Rahadi.2017. Pengaruh corporate social responsibility, mekanisme Good corporate governance, nilai perusahaan, Ukuran perusahaan dan leverage terhadap return saham. Jurnal Pundi. Vol 01 No 
03. Hal 197-212. ISSN 23557052.

Pattiasina,Victor. et al.2018. The Impact of Financial Ratios towards Profit Changes. International Research Journal of Management, IT \& Social Sciences. Vol 5 No 5. Hal 1-16. ISSN : 2395-7492.

Pattisahusiwa,Salmah dan Ferry Diyanti.2018. Pengungkapan corporate social responsibility, struktur corporate governance dan nilai perusahaan. Jurnal Ekonomi Modernisasi. Vol 13 No 1 . Hal 25-36. ISSN : 25024578.

Putra, Ida Bagus Gede Waisaka dan I Made Karya Utama. 2015. Pengaruh Pengungkapan Corporate Social Responsibility Dan Informasi Laba Akuntansi Pada Return Saham. E-Jurnal Akuntansi Universitas Udayana Vol 13 No 1 Hal : 191-207. ISSN: 2302-8556.

Rahayu,Siti.dkk.2015. Pengaruh pengungkapan CSR dan kinerja keuangan terhadap stock return perusahaan di index LQ45 BEI. Jurnal akuntansi UBHARA. Hal 380-394. ISSN : 2460-7762.

Riyadi,Bambang.2017. Profit Analysis With Financial Ratio (Study At Manufacturing In Indonesia Stock Exchange). IOSR Journal of Economics and Finance (IOSRJEF). Vol 8 Issue 5 Ver. IV. Hal 39-43. ISSN : 2321-5933.

Suherman, et al. 2016. The effect of corporate performance on the stocks in the companies doing IPO. Journal of Economics, Business, and Accountancy Ventura Vol 19 No 1. Hal 125-140. DOI : 10.14414/jebav.v19i1.532.

Verawaty,ddk. 2015. Pengaruh Kinerja Keuangan Terhadap Return Saham Pada Perusahaan Pertambangan Yang Terdaftar Di Bursa Efek Indonesia. Akuisisi. Vol 11 No 2. Hal 75-87. ISSN : 2477-2984.

Wardah, Khusniatul.2017. Analisis pengaruh kinerja keuangan terhadap return total saham pada PT Elnusa tahun 2009-2015. Jurnal Maksipreneur. Vol VI No 2. Hal 36 - 55. ISSN : 2527-6638.
Hery.2015. Analisis laporan keuangan. Edisi 1. Yogyakarta : center for academic publishing services, ISBN : 978602-375-059-7.

Manan,Abdul.2017. Aspek hukum dalam penyelenggaraan investasi $d i$ pasar modal syariah indonesia. Cetakan ke-2. Jakarta : Kencana, ISBN : 978-979-1486-66-8.

Martani, Dwi,dkk. 2016. Akuntansi Keuangan Menengah berbasis PSAK. Buku 1 Edisi 2. Jakarta : Salemba Empat, ISBN : 978-979-061-647-9.

Noor,Juliansyah.2017. Metodologi penelitian : Skripsi, tesis, disertasi, dan karya ilmiah. Cetakan ke-7. Jakarta : Kencana, ISBN : 978-602-373082-2.

Sawidji.2015. Pengetahuan pasar modal untuk konteks indonesia. Cetakan pertama. Jakarta : Kompas Gramedia, ISBN : 978-602-026907-8.

Suartini, Sri dan Hari sulistiyo. 2017. Praktikum Analisis Laporan Keuangan Bagi Mahasiswa dan Praktikan. Jakarta : Mitra Wacana Media, ISBN : 978-602-318-2480 .

Sudaryo,Yoyo. dkk.2017. keuangan di era otonomi daerah. Yogyakarta : ANDI, ISBN : 978-979-296362-5.

Sujarweni, V. Wiratna. 2016. Kupas Tuntas Penelitian Akuntansi dengan SPSS. Yogyakarta : Pustaka Baru Press, ISBN : 602-376-041-4.

Sugiyono.2016. Metode penelitian kuantitatif,kualitatif, dan kombinasi (mixed methods). Bandung : Alfabeta, ISBN : 978602-9328-06-6.

Sugiyono. 2018. Metode Penelitian Kuantitatif, Kualitatif, dan $R$ \& D. Bandung : Alfabeta, ISBN : 979-8433-64-0.

Undang-undang Republik Indonesia pasal 74 ayat 1 nomor 40 tahun 2007 tentang perseroan terbatas.

Pemerintah Indonesia. Peraturan Menteri Badan Usaha Milik Negara. Nomor : PER-08/MBU/2013 tentang Perubahan Keempat Atas Peraturan Menteri Negara Badan Usaha Milik Negara Nomor PER- 
05/MBU/2007 Tentang Program

Kemitraan Badan Usaha Milik

Negara Dengan Usaha Kecil Dan

Program Bina Lingkungan.

http://www.neraca.co.id/article/58808/saham-

bumn-tarik-ihsg-ke-level-bawah

diakses pada tanggal 20 Februari 2019.

www.proper.menlh.go.id diakses pada tanggal 26 Desember 2018.

www.iaiglobal.or.id diakses pada tanggal 28 Desember2018.

www.bumn.go.id diakses pada tanggal 04 Januari 2019. 